\title{
Growth of Preterm Born Children
}

\author{
A.M. Euser ${ }^{\mathrm{a}}$ C.C. de Wit ${ }^{\mathrm{a}, \mathrm{b}}$ M.J.J. Finken ${ }^{\mathrm{a}}$ M. Rijken ${ }^{\mathrm{a}}$ J.M. Wit ${ }^{\mathrm{a}}$ \\ a Department of Pediatrics, Leiden University Medical Center, Leiden, The Netherlands; \\ ${ }^{b}$ Department of Paediatrics and the Liggins Institute, University of Auckland, Auckland, New Zealand
}

\section{Key Words}

Growth - Preterm infant $\cdot$ Low-birth-weight infant .

Body size $\cdot$ Body height $\cdot$ Body weight

\begin{abstract}
Background: In this review, we describe the growth of (very) preterm infants or (very) low-birth-weight infants from birth until adulthood. Methods: A systematic analysis of growth of these infants is thwarted by different definitions (classification by gestational age or birth weight) used in the literature. Results: The early postnatal period of these individuals is almost invariably characterized by substantial growth failure. In the majority of preterm infants this is followed by a period of catch-up growth, which starts in early infancy and usually stops at 2-3 years of age, although in some cases it may continue into adolescence. Catch-up growth is usually incomplete, so that infants born preterm remain shorter and lighter than term-born peers during childhood, adolescence, and adulthood. Disproportionate catch-up growth in height and weight may lead to an altered body composition in adulthood, especially in females. Conclusion: Though early catch-up growth has shown to be beneficial for neurodevelopmental outcome, it is also associated with adverse metabolic consequences in adulthood. As the first generation of (very) preterm infants is now reaching young adulthood, future follow-up studies on these effects are warranted.
\end{abstract}

Copyright $\odot 2008$ S. Karger AG, Basel

A.M. Euser and C.C. de Wit contributed equally to this work.

\section{Introduction}

Based on a systematic review of the literature the definitions and determinants of prematurity, prenatal growth, reference charts for preterm born infants, early postnatal growth of the preterm infant, catch-up growth, and growth in childhood, adolescence and adulthood size are discussed, followed by a brief review of late metabolic consequences.

\section{Methods}

We conducted a systematic literature search in PubMed of articles published between 1998 and October 2007. Our search strategy is shown in table 1 . Relevant articles were selected on title and abstract. We primarily focused on original research conducted in the past 10 years in humans and written in English. Additional articles were sought by checking the reference lists of the included articles. Recent review articles that provided comprehensive overviews were also included. For the present paper, we selected approximately $50 \%$ of the encountered articles; a full list can be obtained from the authors.

\section{Definitions}

Preterm birth is defined by the estimated gestational age as a proxy of maturity. Three subgroups are distinguished by the World Health Organisation (WHO): preterm ( $<37$ weeks' gestation), very preterm ( $<32$ weeks),

\section{KARGER \\ Fax +41613061234 \\ E-Mail karger@karger.ch}

www.karger.com (c) 2008 S. Karger AG, Basel

0301-0163/08/0706-0319 $\$ 24.50 / 0$

Accessible online at:

www.karger.com/hre
Prof. Dr. J.M. Wit

Department of Pediatrics, Leiden University Medical Center

Room J6-206, PO Box 9600

NL-2300 RC Leiden (The Netherlands)

Tel. +31 71526 2824, Fax +31 71524 8198, E-Mail j.m.wit@lumc.nl 
Table 1. Search strategy for PubMed

\begin{tabular}{ll}
\hline Search No. \\
\hline 1 & $\begin{array}{l}\text { 'infant, premature' (MeSH terms) or 'premature infant' } \\
\text { (TiAb) or preterm (TiAb) or 'infant, low birth weight' } \\
\text { (MeSH terms) or low birth weight (TiAb) }\end{array}$ \\
\hline 2 & 'growth' (MeSH terms) or growth (TiAb) \\
\hline 3 & $\begin{array}{l}\text { growth (Ti) or 'cohort studies' (MeSH terms) or cohort } \\
\text { studies (TiAb) or cohort study (TiAb) or 'body height' } \\
\text { (MeSH terms) or body height (TiAb) or 'body weight' } \\
\text { (MeSH terms) or body weight (TiAb) }\end{array}$ \\
\hline 5 & 1 and 2 and 3 limits: publication date from 1998, humans \\
\hline
\end{tabular}

and extremely preterm ( $<28$ weeks) [1]. In the United States of America and several other countries a classification according to birth weight is generally used. Lowbirth-weight infants are defined as those with a birth weight of 2,500 g or less, which may be due to prematurity, being born small for gestational age (SGA), or both. Similarly, lower cut-off limits for weight have been used to describe more severe cases, i.e. very low birth weight (VLBW $<1,500 \mathrm{~g}$ ) [2,3] and extremely low birth weight $($ ELWB $<1,000 \mathrm{~g})$ [4]. In very preterm and/or VLBW infants, gestational age is a better predictor of short-term survival than birth weight [5]. The decision about which parameter is applied to define a cohort of small infants has considerable consequences for the characteristics of the population studied.

\section{Determinants of Prematurity and Low Birth Weight}

\section{Determinants of Prematurity}

Various risk factors have been consistently associated with premature birth, such as multiple pregnancy, low socioeconomic status, African-American origin, second teenage pregnancy, parity and past reproductive history, substance misuse, infection and hypertensive disease during pregnancy [6]. Approximately $14 \%$ of the variation in gestational age is explained by maternal genetic factors, and $11 \%$ by fetal genetic factors [7]. The effect of specific polymorphisms in the foetus, e.g. in genes encoding immunologic or haemostatic proteins, seems to be modest compared to maternal risk factors [8].

\section{Determinants of a Low Birth Weight for \\ Gestational Age}

The risk factors for SGA are usually divided into foetal, placental, and maternal factors, the latter including maternal age, height, and parity [9, for details see 10]. Foetal genetic factors explained $31 \%$ of the normal variation in birth weight and birth length and $27 \%$ of the variation in head circumference; maternal genetic factors explained $22 \%$ of the variation in birth weight, and $19 \%$ of the variation in birth length and head circumference [7]. One of the foetal genes involved may be insulin, as polymorphisms in its promoter are associated with size at birth [10]. Paternally and maternally imprinted genes oppose each other in the regulation of foetal growth and development, illustrated by observations that genomic imprinting of the IGF-II gene has a considerable effect on foetoplacental development and thus delivery of nutrients to the foetus [10]. Although the variation in birth weight may be mainly caused by differences in growth in the third trimester, there is recent evidence that both the growth trajectory of the fetus and its adaptive responses to the prenatal and postnatal environment may be determined as early as the period around the time of conception $[11,12]$.

\section{Prenatal Growth}

\section{$S G A$}

At birth, the newborn can have an appropriate weight and/or length for gestational age (AGA), be small for gestational age in weight and/or length (SGA), or large for gestational age (LGA) [13]. Ideally, the cut-off limit for SGA should best discriminate between infants who are at high risk of short-term and long-term growth impairment, disease, and death, and those who are at a low risk [14]. However, in practice there are various cut-off limits based on arbitrary statistical criteria. Among paediatric endocrinologists there is consensus that a birth weight and/or length of $<-2$ SDS should be the cut-off value [9, 15]. Neonatologists tend to use the 5th or 10th percentile for gestational age [16], since these cut-offs are related to later developmental problems.

Within the SGA population, three subgroups can be distinguished; infants with a low weight but normal length for gestational age (SGA $\mathrm{SW}_{W}$ or SWGA), infants with a low length but normal weight for gestational age (SGA or SLGA), and infants with the combination of both $\left(S_{G A}\right.$ or SLWGA) $[17,18]$. The growth patterns of the three subgroups are somewhat different $[17,19]$ and 
SLWGA males have on average a poorer neurologic outcome than those born SWGA but not SLGA [20].

We have previously argued that the third auxological parameter that should be measured at birth is head circumference. $\mathrm{SGA}_{\mathrm{H}}$ or SHGA could be added to the nomenclature to indicate a small head circumference for gestational age [21], which is indicative for early intrauterine growth retardation or, in extreme cases, for a decreased biological effect of IGF-1 due to primary IGF-I deficiency or resistance [22].

\section{SGA versus IUGR}

Formerly, the terms SGA and intrauterine growth restriction (IUGR) were used for the same condition, but nowadays there is consensus that the term IUGR should be limited to the process of decreased intrauterine growth rate detected by - preferably several - ultrasound measurements $[9,15]$. If prolonged and/or severe enough, this may lead to the delivery of an SGA infant. SGA refers only to the condition at birth $[15,18,21]$. When the prenatal growth pattern is unknown, SGA may be regarded as a proxy for IUGR [14].

\section{References and Standards for Birth Size for}

Gestational Age

For the classification of prematurity, a reliable estimate of gestational age is necessary. This is usually performed by combining information on the last menstrual period, and early ultrasound assessment [2], but neither is perfectly reliable [23]. It is noteworthy that according to international recommendations gestational age is expressed in complete weeks $[24,25]$, while in the frequently used reference of Usher and McLean gestational age was calculated to the nearest week from the last normal menstrual period [26]. In the former approach, the reference curves are shifted to the left by half a week, which appears irrational.

For the classification of SGA (or LGA) versus AGA, anthropometric data are compared with reference charts for gestational age. Ideally, up-to-date reference data from the same or a similar population are required [14]. The choice of the reference population has a considerable impact on the classification, especially for preterm infants [27].

Currently used neonatal charts differ substantially, and there are essentially four types of diagrams:

(1) Most reference charts are based on the birth size of all newborns in a certain area or country and are presented separately for boys and girls. The American charts (by Lubchenco $[28,29]$ and later by Usher and McLean
[26]) are based on small samples (so that combined charts for males and females were prepared) and it was shown recently that both are inaccurate for use in current populations in the US [30]. For Northern European countries the Swedish reference is most appropriate $[24,31]$.

(2) In some countries separate reference charts are used for primipara and multipara mothers, and for different ethnic groups [32].

(3) Conditional, customized charts are based on various conditions with a known impact on birth weight weighted in a computer model in order to calculate the degree of normality [33]. On top of adjustments for foetal sex, gestational age and parity, additional adjustments are made for a number of characteristics such as maternal height, weight at first antenatal clinic visit, ethnic group [34], maternal birth weight and birth weight of previous siblings [35]. These charts are primarily used by obstetricians.

(4) 'Standard' charts are based on intrauterine growth measurements in babies subsequently born at term, from which birth weight is calculated [36]. While these charts have a high sensitivity in detecting a neonate with a growth anomaly, calculating body weight from ultrasound measurements leads to an inevitable loss of precision, so that many centres continue to use regular reference charts based on birth weight data [37].

\section{Early Postnatal Growth}

In the first weeks of extra-uterine life, (very) preterm infants often develop cumulative energy and protein deficits, despite caloric and protein supplements at recommended intakes [38]. Even with active regimens of parenteral and/or early enteral feeding [39], this causes on average a substantial postnatal growth failure, with growth curves that are sharply deviating from the reference data [40-44].

The typical growth pattern is an initial postnatal weight loss (the lowest weight is reached at the fourth to seventh day), followed by an early neonatal peak in growth velocity mimicking in utero growth rates beginning in the second week of life. Birth weight is usually regained in the period between the 8th to the 24th day of life, but earlier in infants with higher birth weights $[39,40,45]$. Typically, VLBW infants have weights less than the 10th percentile at 36 weeks' postmenstrual age [42], and have an average weight at 40 weeks postmenstrual age of -2.6 SDS [46]. In cohorts based on a low birth weight, the relatively high proportion of SGA infants has a negative ef- 
fect on growth outcome. While weight is the most documented auxological parameter during these first weeks, also extra-uterine growth restriction with regard to length and head circumference is common [43].

Although preterm infants are usually lighter and shorter at 40 weeks after the last menstrual period than term born infants, no difference in total adiposity was found. Moreover, preterm infants had an altered fat distribution, with a decrease in subcutaneous fat and an increase in intra-abdominal adipose tissue [47]. At 1 year of age, still a slightly greater fat mass normalized for weight was found in infants born $<34$ weeks of gestation [48].

\section{Factors Influencing Early Growth}

Preterm infants are often admitted to a Neonatal Intensive Care Unit (NICU), and face the consequences of unintended postnatal life such as respiratory distress syndrome, bronchopulmonary dysplasia, necrotizing enterocolitis, and infections, with concomitant treatment regimens of, e.g., mechanical ventilation, parenteral nutrition, and administration of steroids [43, 49]. Both illness severity and clinical practice in treatment and nutrition vary widely between infants and between NICUs as well $[50,51]$.

A low birth weight and gestational age $[43,44]$, postnatal dexamethasone $[43,49]$, a long duration of respiratory support [49], pulmonary and circulatory problems [44], severity of illness [45], infections [43, 44], NEC [43, 44], and male sex [43] have been negatively associated with early postnatal growth. On a biological level, an important mediator of the early postnatal growth in preterm infants may be IGF-1 [52-54]. Not surprisingly, a very important factor that has been positively related to growth in early life is caloric intake $[38,49,55]$.

\section{Postnatal Growth References}

The non-physiological situation of preterm birth makes it difficult to provide appropriate postnatal growth references in order to distinguish postnatal growth failure from growth that is normal for this specific group. Separate growth references for infants with parenteral and/or early nutrition have been suggested $[39,56]$, but generally the charts of birth weight, length and head circumference for gestational age are used. Postnatal growth failure has been defined as weight below the 10th centile at 36 weeks corrected gestational age [41], or as a decrease in $\mathrm{z}$-score of $>2$ between birth and 36 weeks corrected gestational age [57]. We have coined the term 'preterm growth restraint' (PGR) to indicate poor growth in the third trimester, either spent in utero (the term born SGA infant ) or ex utero (the preterm born infant with a normal weight for gestational age, but a low length and/or weight at term age, i.e. $<-2$ SDS) [58].

\section{Catch-Up Growth}

\section{Catch-Up Growth}

Catch-up growth is usually defined as reaching an SD score of $>-2$ SDS of the reference population [9], but in other studies a change $>0.67$ SD has been used as cut-off [59]. Similar to term infants born SGA, most preterm born infants (approximately 80\%) show catch-up growth in weight, length and head circumference after initial postnatal growth failure [60-63], generally starting early in the first months of life and often achieved within the first 2 years of life [60-62, 64, 65]. However, late catch-up growth of preterm subjects has been described throughout childhood $[62,63]$ and even in adolescence [66-68].

It is generally considered that catch-up growth in weight, length, and particularly in head circumference is important for neurodevelopmental outcome [69-71]. Motor impairment was less common if preterm infants were fed an enriched preterm formula in comparison to a regular term formula in the first month after birth [72], especially in males [73]. However, on average adolescents born very preterm have decreased brain volumes compared to term controls [74].

\section{Determinants of Catch-Up Growth}

Little is known about the factors that determine if catch-up growth occurs in preterm infants and whether it is complete. Also for term born SGA infants these questions have not been fully elucidated, but birth length and target height [75], a lower serum leptin, lower birth weight, early weaning from the ventilator and plasma IGF-I are associated with catch-up growth in weight $[76,77]$.

In preterm infants early growth and genetic potential as reflected by parental height seem important for catchup growth in height as well, though this effect might be different for different durations of gestation [62, 63, 67, $78,79]$. Examples of specific genetic polymorphisms that have both been related to increased postnatal catch-up growth in preterm infants are the $\mathrm{d} 3$-isoform polymorphism of the growth hormone receptor gene [80], and the $\mathrm{R} 23 \mathrm{~K}$ polymorphism in the glucocorticoid receptor gene [81].

Recently, a prediction model was presented on growth of a cohort of very low birth weight survivors. The following factors explained height SDS at 5 years: height SDS at 
Table 2. Early postnatal and childhood growth of preterm, LWB, VLBW and ELBW infants

\begin{tabular}{|c|c|c|c|c|c|c|c|c|c|c|}
\hline & $\mathrm{n}$ & $\begin{array}{l}\text { Inclusion } \\
\text { criteria birth } \\
\text { weight/ } \\
\text { gestational age }\end{array}$ & $\begin{array}{l}\text { Mean } \\
\text { gestational } \\
\text { age, weeks }\end{array}$ & $\begin{array}{l}\text { Mean birth } \\
\text { weight, g }\end{array}$ & $\begin{array}{l}\text { Mean } \\
\text { birth weight } \\
\text { SDS }\end{array}$ & $\begin{array}{l}\text { Percentage } \\
\text { SGA at } \\
\text { birth }\end{array}$ & $\begin{array}{l}\text { Measure } \\
\text { point }\end{array}$ & $\begin{array}{l}\text { Percentage } \\
\text { growth fail- } \\
\text { ure at mea- } \\
\text { sure point }\end{array}$ & $\begin{array}{l}\text { Height } \\
\text { Z-score at } \\
\text { measure } \\
\text { point }\end{array}$ & $\begin{array}{l}\text { Weight } \\
\text { Z-score at } \\
\text { measure } \\
\text { point }\end{array}$ \\
\hline $\begin{array}{l}\text { Fewtrell, } \\
2000[78]\end{array}$ & 765 & $\begin{array}{l}\text { 'preterm' } \\
\text { and }<1,850 \mathrm{~g}\end{array}$ & 31.0 & 1,364 & & & $\begin{array}{l}18 \text { months } \\
7.5-8 \text { years } \\
9-12 \text { years }\end{array}$ & & $\begin{array}{l}-0.91 \\
-0.47 \\
-0.44\end{array}$ & \\
\hline $\begin{array}{l}\text { Lemons, } \\
2001 \text { [42] }\end{array}$ & 4,438 & $501-1,500 \mathrm{~g}$ & & & & $22^{\mathrm{a}}$ & 36 weeks $^{\mathrm{b}}$ & $97^{a}$ & & \\
\hline $\begin{array}{l}\text { Niklasson, } \\
2003 \text { [91] }\end{array}$ & 52 & $<29$ weeks & & $\begin{array}{l}28 \text { weeks } 1,180 \\
27 \text { weeks } 1,015 \\
\leq 26 \text { weeks } 720\end{array}$ & & & $\begin{array}{l}40 \text { weeks }^{\mathrm{b}} \\
6 \text { months } \\
3 \text { years } \\
7 \text { years }\end{array}$ & $\begin{array}{l}19.2^{\mathrm{c}} \\
5.8^{\mathrm{c}}\end{array}$ & $\begin{array}{l}-1.08 \\
-1.70 \\
-0.60 \\
+0.09\end{array}$ & $\begin{array}{l}-0.19 \\
-1.73 \\
-0.88 \\
-0.02\end{array}$ \\
\hline $\begin{array}{l}\text { Bertino, } \\
2006 \text { [45] }\end{array}$ & 262 & $500-1,500 \mathrm{~g}$ & 30.4 & 1,140 & -0.98 & $38.5^{\mathrm{a}}$ & $\begin{array}{l}40 \text { weeks }^{\mathrm{b}} \\
2 \text { years }\end{array}$ & $\begin{array}{l}100^{\mathrm{d}} \\
100^{\mathrm{e}}\end{array}$ & & \\
\hline $\begin{array}{l}\text { Saigal, } \\
2006 \text { ㅇ [66] }\end{array}$ & 82 & $<1,000 \mathrm{~g}$ & 27.2 & 838 & & $28^{\mathrm{a}}$ & $\begin{array}{l}1 \text { year } \\
2 \text { years } \\
8 \text { years }\end{array}$ & & $\begin{array}{l}-1.04 \\
-0.77 \\
-0.94\end{array}$ & $\begin{array}{l}-1.96 \\
-1.68 \\
-1.05\end{array}$ \\
\hline $\begin{array}{l}\text { Saigal, } \\
2006 \text { \& [66] }\end{array}$ & 65 & $<1,000 \mathrm{~g}$ & 27.0 & 844 & & $20^{\mathrm{a}}$ & $\begin{array}{l}1 \text { year } \\
2 \text { years } \\
8 \text { years } \\
\end{array}$ & & $\begin{array}{l}-1.59 \\
-0.92 \\
-0.84 \\
\end{array}$ & $\begin{array}{l}-2.49 \\
-1.90 \\
-1.05 \\
\end{array}$ \\
\hline $\begin{array}{l}\text { Trebar, } \\
2007 \text { [62] }\end{array}$ & 1,320 & $<1,500 \mathrm{~g}$ & 29.17 & 1,097 & -1.16 & $55.3^{\mathrm{a}}$ & $\begin{array}{l}1.8 \text { years } \\
4.0 \text { years } \\
6.1 \text { years }\end{array}$ & $\begin{array}{l}13.3^{\mathrm{c}} \\
18.2^{\mathrm{c}} \\
11.1^{\mathrm{c}}\end{array}$ & $\begin{array}{l}-0.69 \\
-0.93 \\
-0.62\end{array}$ & $\begin{array}{l}-1.28 \\
-1.32 \\
-0.85\end{array}$ \\
\hline $\begin{array}{l}\text { Hovi, } \\
2007 \text { [46] }\end{array}$ & 166 & $600-1,500 \mathrm{~g}$ & $29.17 \pm 2.22$ & & $-1.29 \pm 1.51$ & $33.1^{\mathrm{c}}$ & 40 weeks $^{\mathrm{b}}$ & & & $-2.6 \pm 1.15$ \\
\hline $\begin{array}{l}\text { Bracewell, } \\
2008 \text { [89] }\end{array}$ & 241 & $<25^{6}$ & & & $\begin{array}{l}\leq 23 \text { weeks }+0.70 \\
24 \text { weeks }+0.37 \\
25 \text { weeks }+0.07\end{array}$ & & 6 years & & -0.95 & -1.18 \\
\hline
\end{tabular}

${ }^{a}$ As defined $<10$ th percentile for weight at birth; ${ }^{b}$ postmenstrual age; ${ }^{c}$ as defined $<-2.0$ SDS for weight and/or height; ${ }^{\mathrm{d}}$ as defined $<3 \mathrm{rd}$ percentile for weight; ${ }^{\mathrm{e}}$ as defined $<25$ th percentile for weight.

1 year, mid-parental height SDS, 1st year weight SDS, and birth weight SDS [62]. We have shown that infants born very preterm who reach the normal range for length $(>-2$ SDS) at 3 months post-term display a virtually normal growth pattern in childhood, adolescence and adulthood, but infants who do not catch up (labelled pre-term growth restraint, PGR) show a similar growth pattern as term born SGA babies. In approximately $10 \%$ of them length remains below the -2 SDS line [65]. Most studies have shown that postnatal corticosteroid treatment has a negative effect on postnatal catch-up [64, 82, 83], but others did not find such effect $[61,84-86]$. Other factors that have been negatively related to later (catch-up) growth in preterm infants include male gender [3], medical complications [87] and being born SGA [60-63, 88].

\section{Growth and Body Composition}

\section{Growth in Childhood}

With respect to growth in early and mid-childhood, the general pattern reported is that despite catch-up growth (if defined by reaching a height within the normal range) and a steady increase in SDS or z-score for all anthropometric measurements [61, 62, 89], both male and female infants born preterm remain smaller and lighter with a smaller head circumference than their term-born or normal birth weight peers $[62,66,78,89]$, particularly if they were born SGA $[60-63,88,90]$ (table 2). The data in table 2 , collected from recent studies, however, indicate that there is likely to be a trend towards normal height and weight after a decrease in $\mathrm{z}$-scores in the first 
Table 3. Growth of preterm and LBW infants in puberty and adulthood

\begin{tabular}{|c|c|c|c|c|c|}
\hline & $\mathrm{n}$ & $\begin{array}{l}\text { Inclusion criteria birth } \\
\text { weight or gestational age }\end{array}$ & $\begin{array}{l}\text { Age } \\
\text { years }\end{array}$ & $\begin{array}{l}\text { Height } \\
\text { z-score }\end{array}$ & $\begin{array}{l}\text { Weight } \\
\text { z-score }\end{array}$ \\
\hline Hack, 2003 s [3] & 103 & $<1,500 \mathrm{~g}$ & 20 & -0.44 & -0.35 \\
\hline Hack, 2003 + [3] & 92 & $<1,500 \mathrm{~g}$ & 20 & -0.26 & +0.26 \\
\hline Doyle, 2004 [68] & 42 & $500-999 \mathrm{~g}$ & 20 & -0.52 & +0.14 \\
\hline Brandt, 2005 [67] & 21 & $<1,000 \mathrm{~g}, \mathrm{SGA}^{*}$ and preterm ${ }^{* *}$ & 22.8 & -1.02 & \\
\hline Euser, $2005+$ [96] & 216 & $<32$ weeks & 19 & -0.60 & -0.48 \\
\hline Euser, $2005 \delta[96]$ & 187 & $<32$ weeks & 19 & -0.55 & -0.41 \\
\hline Farooqi, 2006 [79] & 83 & $<26$ weeks & 11 & -0.53 & -0.15 \\
\hline Saigal, 2006 [66] & 82 & $<1,000 \mathrm{~g}$ & $11-16$ & -0.59 & -0.24 \\
\hline Saigal, $2006 \_[66]$ & 65 & $<1,000 \mathrm{~g}$ & $11-16$ & -0.46 & -0.53 \\
\hline
\end{tabular}

* SGA as defined <10th percentile for height and/or weight; ** preterm birth undefined.

years of life. Only one study reported that preterm infants born $<29$ weeks of gestation as a group reached normal weight, height, and weight for height before puberty [91]. With regard to body composition in infancy, a reduced fat mass when normalized for height at age 8-12 years was observed in children born $<37$ weeks of gestation [92].

\section{Growth in Adolescence and Adulthood}

In studies describing growth of preterm infants reaching adolescence (table 3), puberty has not always been accurately reported. This complicates a comparison between studies, as puberty has an important effect on growth velocity [78]. Studies reporting puberty have shown no difference in the timing of puberty between preterm born adolescents and term controls $[3,66,68]$. In adolescence, upwards percentile crossing has been reported [66-68, 93, 94], but adolescents born preterm generally continue to be shorter in puberty than term born controls $[66,79]$.

An increasing number of studies have reported data on adult height in preterm born individuals (table 3), but one should note that these studies only concern the very preterm and very or extremely low birth weight population, from which severely handicapped subjects are usually excluded. Growth data of individuals born preterm at a more advanced gestational age are scarce. Mean height of young adults born (very) preterm is shorter than that of term-born controls $[66,68,95]$ and than target height [66]. Again, preterm infants born SGA are at higher risk of short stature, as only $46 \%$ of SGA-VLBW born young adults showed complete catch-up [67].

\section{Adult Weight and Body Composition}

Young adults born (very) preterm weigh less than the average population [66] (6.5 and $7.1 \mathrm{~kg}$ for males and females) [66]. However, catch-up for weight of individuals born preterm is generally more pronounced than catchup in height (table 3). The mean BMI that has been reported in young adulthood is close to that of the reference population in most studies [66,96], but lower [95] and higher $[3,68]$ percentages of overweight have been reported, particularly in females.

One of the cohorts that has been followed up to young adulthood is the POPS cohort, consisting of infants born very preterm and/or with a very low birth weight $[96,97]$. In young adulthood, the average height SDS was -0.55 and -0.60 for males and females respectively, but BMI SDS was -0.10 and -0.17 , and waist circumference SDS +0.24 for males and even +0.73 for females [96]. This indicates that the altered fat distribution at term age noted in preterm born infants might persist into adulthood, which might in turn contribute to a less favourable cardiovascular disease risk profile $[47,96]$.

\section{Late Metabolic Consequences of Preterm Birth}

Since the original observations of Barker and collaborators [98-101], a wealth of studies have shown an association between low birth weight and adult metabolic diseases like obesity, type 2 diabetes, hypertension and cardiovascular incidents. More recently, it has been shown that especially the combination of small size at birth followed by increased catch-up growth in later life is detrimental for adult cardiovascular health [102-104]. Al- 
though these findings have been confirmed in animal studies, one should realize that in the human all 'evidence' results from epidemiological studies. The mechanism behind these associations has remained obscure thus far $[105,106]$. In the majority of the original publications, no clear distinction has been made between low birth weight due to term SGA or due to preterm birth, and the number of preterm subjects included is very low.

It has been speculated that individuals born preterm experience similar metabolic consequences in adult life as term born individuals with low birth weight $[107,108]$. The third trimester is a critical developmental period, and malnutrition during this time span has been related to reduced adult glucose tolerance in the Dutch famine studies [109]. Infants born preterm almost invariably experience postnatal growth failure during this time window, often followed by later catch-up growth. Evidence for this similarity in adverse metabolic sequelae in adulthood between term SGA infants and infants born preterm mostly results from studies on glucose tolerance and blood pressure during childhood and young adulthood in preterm or VLBW survivors (recently reviewed by Hofman et al. [107]). Both in the neonatal period [110] and in childhood $[111,112]$, individuals born (very) preterm have a decreased insulin tolerance.

Survivors of preterm birth are still too young to allow for studying the effect on full-blown cardiovascular disease, and studies are limited to early markers of cardiovascular disease in young adulthood. In a recent study, glucose tolerance was reduced in a cohort of VLBW young adults [46], and in the POPS study we found that insulin sensitivity at 19 years of age in individuals born very preterm was particularly decreased if BMI in young adulthood was relatively high [113]. No associations were observed between early growth and intima-media thickness [114]. With respect to blood pressure, we found an increased incidence of hypertension and borderline hypertension [115], in accordance with other studies [116, 117], irrespective of nephrocalcinosis [118].

\section{Conclusion}

Individuals born preterm usually show a substantial growth failure in the early postnatal period, which is usually followed by catch-up growth over $2-3$ years, but a slightly lower mean adult height than term born peers. Although catch-up growth is beneficial for neurodevelopmental outcome, it might lead to adverse metabolic consequences in adulthood. Future follow-up studies on these effects are warranted.

\section{Acknowledgements}

We gratefully thank Mrs. Brand-De Heer, Walaeus Library Leiden University Medical Center, for her expertise and guidance in developing a systematic and appropriate search strategy for identification of studies.

\section{References}

1 International Classification of Diseases (ICD) 10: WHO, 2007. Internet communication.

2 Sherry B, Mei Z, Grummer-Strawn L, Dietz $\mathrm{WH}$ : Evaluation of and recommendations for growth references for very low birth weight $(<$ or $=1500$ grams $)$ infants in the United States. Pediatrics 2003;111:750-758.

- 3 Hack M, Schluchter M, Cartar L, Rahman M, Cuttler L, Borawski E: Growth of very low birth weight infants to age 20 years. Pediatrics 2003;112:e30-e38.

4 Valcamonico A, Accorsi P, Sanzeni C, Martelli P, La BP, Cavazza A, Frusca T: Mid- and long-term outcome of extremely low birth weight (ELBW) infants: an analysis of prognostic factors. J Matern Fetal Neonatal Med 2007;20:465-471.

5 Verloove P, Verwey RA, Brand R, Keirse MJ: Importance of gestational age. Lancet 1986;i:1494

\footnotetext{
6 Slattery MM, Morrison JJ: Preterm delivery. Lancet 2002;360:1489-1497.

7 Lunde A, Melve KK, Gjessing HK, Skjaerven R, Irgens LM: Genetic and environmental influences on birth weight, birth length, head circumference, and gestational age by use of population-based parent-offspring data. Am J Epidemiol 2007;165:734-741.

8 DeFranco E, Teramo K, Muglia L: Genetic influences on preterm birth. Semin Reprod Med 2007;25:40-51.

9 Lee PA, Chernausek SD, Hokken-Koelega AC, Czernichow P: International Small for Gestational Age Advisory Board consensus development conference statement: management of short children born small for gestational age, April 24-October 1, 2001. Pediatrics 2003;111:1253-1261.
}

10 Saenger P, Czernichow P, Hughes I, Reiter EO: Small for gestational age: short stature and beyond. Endocr Rev 2007;28:219-251.

11 Smith GC, Smith MF, McNay MB, Fleming JE: First-trimester growth and the risk of low birth weight. N Engl J Med 1998;339:18171822.

12 Bukowski R, Smith GC, Malone FD, Ball RH, Nyberg DA, Comstock CH, Hankins GD, Berkowitz RL, Gross SJ, Dugoff L, Craigo SD, Timor-Tritsch IE, Carr SR, Wolfe HM, D'Alton ME: Fetal growth in early pregnancy and risk of delivering low birth weight infant: prospective cohort study. BMJ 2007;

334:836.
Battaglia FC, Lubchenco LO: A practical classification of newborn infants by weight and gestational age. J Pediatr 1967;71:159163. 
14 Bertino E, Milani S, Fabris C, De CM: Neonatal anthropometric charts: what they are, what they are not. Arch Dis Child Fetal Neonatal Ed 2007;92:F7-F10.

15 Clayton PE, Cianfarani S, Czernichow P, Johannsson G, Rapaport R, Rogol A: Management of the child born small for gestational age through to adulthood: a consensus statement of the International Societies of Pediatric Endocrinology and the Growth Hormone Research Society. J Clin Endocrinol Metab 2007;92:804-810.

16 Anderson MS, Hay WW Jr: Intrauterine growth restriction and the small for gestational age infant; in Avery GB, Fletcher MA, MacDonald MG (eds): Neonatology. Philadelphia, Lippincott, Williams \& Wilkins, 1999, p 411.

17 Karlberg J, Albertsson-Wikland K: Growth in full-term small-for-gestational-age infants: from birth to final height. Pediatr Res 1995;38:733-739.

18 Laron Z, Mimouni F: Confusion around the definition of small for gestational age (SGA). Pediatr Endocrinol Rev 2005;2:364-365.

-19 Albertsson-Wikland K, Karlberg J: Natural growth in children born small for gestational age with and without catch-up growth. Acta Paediatr Suppl 1994;399:64-70.

-20 Lundgren EM, Cnattingius S, Jonsson B, Tuvemo T: Intellectual and psychological performance in males born small for gestational age with and without catch-up growth. Pediatr Res 2001;50:91-96.

-21 Wit JM, Finken MJ, Rijken M, Walenkamp MJ, Oostdijk W, Veen S: Confusion around the definition of small for gestational age. Pediatr Endocrinol Rev 2005;3:52-53.

22 Walenkamp MJ, Wit JM: Genetic disorders in the growth hormone-insulin-like growth factor-I axis. Horm Res 2006;66:221-230.

-23 Savitz DA, Terry JW, Jr, Dole N, Thorp JM, Jr, Siega-Riz AM, Herring AH: Comparison of pregnancy dating by last menstrual period, ultrasound scanning, and their combination. Am J Obstet Gynecol 2002; 187:1660 1666.

-24 Niklasson A, Ericson A, Fryer JG, Karlberg J, Lawrence C, Karlberg P: An update of the Swedish reference standards for weight, length and head circumference at birth for given gestational age (1977-1981). Acta Paediatr Scand 1991 80;756-762.

-25 Kramer MS, Platt RW, Wen SW, Joseph KS, Allen A, Abrahamowicz M, Blondel B, Breart G: A new and improved population-based Canadian reference for birth weight for gestational age. Pediatrics 2001;108:E35.

26 Usher RH, McLean FH: Intrauterine growth of live-born Caucasian infants at sea level: standards obtained from measurements in 7 dimensions of infants born between 25 and 44 weeks of gestation. J Pediatr 1969;74:901910.
27 Hemming K, Hutton JL, Glinianaia SV, Jarvis SN, Platt MJ: Differences between European birthweight standards: impact on classification of 'small for gestational age'. Dev Med Child Neurol 2006;48:906-912.

-28 Lubchenco LO, Hansman C, Dressler M, Boyd E: Intrauterine growth as estimated from liveborn birth-weight data at 24 to 42 weeks of gestation. Pediatrics 1963;32:793800.

29 Lubchenco LO, Hansman C, Boyd E: Intrauterine growth in length and head circumference as estimated from live births at gestational ages from 26 to 42 weeks. Pediatrics 1966;37:403-408.

30 Thomas P, Peabody J, Turnier V, Clark RH: A new look at intrauterine growth and the impact of race, altitude, and gender. Pediatrics 2000;106:E21.

31 Niklasson A, Bertsson-Wikland K: Continuous growth reference from 24 th week of gestation to 24 months by gender. BMC Pediatr 2008;8:8.

32 Kloosterman GJ: On intrauterine growth. The significance of prenatal care. Int J Gynaecol Obstet 1970;8:895-912.

33 Gardosi J, Chang A, Kalyan B, Sahota D, Symonds EM: Customised antenatal growth charts. Lancet 1992;339:283-287.

34 De Jong CL, Francis A, Van Geijn HP, Gardosi J: Customized fetal weight limits for antenatal detection of fetal growth restriction. Ultrasound Obstet Gynecol 2000;15:36-40.

35 McCowan LM, Harding JE, Stewart AW Customized birthweight centiles predict SGA pregnancies with perinatal morbidity. BJOG 2005;112:1026-1033.

36 Cooke RW: Conventional birth weight standards obscure fetal growth restriction in preterm infants. Arch Dis Child Fetal Neonatal Ed 2007;92:F189-F192.

37 Ehrenkranz RA: Estimated fetal weights versus birth weights: should the reference intrauterine growth curves based on birth weights be retired? Arch Dis Child Fetal Neonatal Ed 2007;92:F161-F162.

-38 Embleton NE, Pang N, Cooke RJ: Postnatal malnutrition and growth retardation: an inevitable consequence of current recommendations in preterm infants? Pediatrics 2001; 107:270-273.

39 Pauls J, Bauer K, Versmold H: Postnatal body weight curves for infants below $1,000 \mathrm{~g}$ birth weight receiving early enteral and parenteral nutrition. Eur J Pediatr 1998;157:416-421.

40 Ehrenkranz RA, Younes N, Lemons JA, Fanaroff AA, Donovan EF, Wright LL, Katsikiotis V, Tyson JE, Oh W, Shankaran S, Bauer CR, Korones SB, Stoll BJ, Stevenson DK, Papile LA: Longitudinal growth of hospitalized very low birth weight infants. Pediatrics 1999;104:280-289.

41 Ehrenkranz RA: Growth outcomes of very low-birth weight infants in the newborn intensive care unit. Clin Perinatol 2000;27: 325-345.
42 Lemons JA, Bauer CR, Oh W, Korones SB, Papile LA, Stoll BJ, Verter J, Temprosa M, Wright LL, Ehrenkranz RA, Fanaroff AA, Stark A, Carlo W, Tyson JE, Donovan EF, Shankaran S, Stevenson DK: Very low birth weight outcomes of the National Institute of Child health and human development neonatal research network, January 1995 through December 1996. NICHD Neonatal Research Network. Pediatrics 2001;107:E1.

43 Clark RH, Thomas P, Peabody J: Extrauterine growth restriction remains a serious problem in prematurely born neonates. Pediatrics 2003;111:986-990.

-44 Marks KA, Reichman B, Lusky A, Zmora E: Fetal growth and postnatal growth failure in very-low-birthweight infants. Acta Paediatr 2006;95:236-242.

-45 Bertino E, Coscia A, Mombro M, Boni L, Rossetti G, Fabris C, Spada E, Milani S: Postnatal weight increase and growth velocity of very low birthweight infants. Arch Dis Child Fetal Neonatal Ed 2006;91:F349-F356.

46 Hovi P, Andersson S, Eriksson JG, Jarvenpaa AL, Strang-Karlsson S, Makitie O, Kajantie E: Glucose regulation in young adults with very low birth weight. N Engl J Med 2007; 356:2053-2063.

-47 Uthaya S, Thomas EL, Hamilton G, Dore CJ, Bell J, Modi N: Altered adiposity after extremely preterm birth. Pediatr Res 2005;57: 211-215.

48 Cooke RJ, Rawlings DJ, McCormick K, Griffin IJ, Faulkner K, Wells JC, Smith JS, Robinson SJ: Body composition of preterm infants during infancy. Arch Dis Child Fetal Neonatal Ed 1999;80:F188-F191.

49 Berry MA, Conrod H, Usher RH: Growth of very premature infants fed intravenous hyperalimentation and calcium-supplemented formula. Pediatrics 1997;100:647-653.

50 Olsen IE, Richardson DK, Schmid CH, Ausman LM, Dwyer JT: Intersite differences in weight growth velocity of extremely premature infants. Pediatrics 2002;110:1125-1132.

-51 Blackwell MT, Eichenwald EC, McAlmon K, Petit K, Linton PT, McCormick MC, Richardson DK: Interneonatal intensive care unit variation in growth rates and feeding practices in healthy moderately premature infants. J Perinatol 2005;25:478-485.

52 Kajantie E, Dunkel L, Rutanen EM, Seppala M, Koistinen R, Sarnesto A, Andersson S: IGF-I, IGF binding protein (IGFBP)-3, phosphoisoforms of IGFBP-1, and postnatal growth in very low birth weight infants. J Clin Endocrinol Metab 2002;87:2171-2179.

53 Ahmad I, Zaldivar F, Iwanaga K, Koeppel R, Grochow D, Nemet D, Waffarn F, Eliakim A, Leu SY, Cooper DM: Inflammatory and growth mediators in growing preterm infants. J Pediatr Endocrinol Metab 2007;20: 387-396. 
54 Executive Summary of the Third Report of The National Cholesterol Education Program (NCEP) Expert Panel on Detection, Evaluation, and Treatment of High Blood Cholesterol in Adults (Adult Treatment Panel III). JAMA 2001 285;2486-2497.

55 Vohr BR, McKinley LT: The challenge pays off: early enhanced nutritional intake for VLBW small-for-gestation neonates improves long-term outcome. J Pediatr 2003; 142:459-461.

56 Diekmann M, Genzel-Boroviczeny O, Zoppelli L, von Poblotzki M: Postnatal growth curves for extremely low birth weight infants with early enteral nutrition. Eur J Pediatr 2005; 164:714-723.

- 57 Shah PS, Wong KY, Merko S, Bishara R, Dunn M, Asztalos E, Darling PB: Postnatal growth failure in preterm infants: ascertainment and relation to long-term outcome. J Perinat Med 2006;34:484-489.

58 Wit JM, Finken MJ, Rijken M, de Zegher F: Preterm growth restraint: a paradigm that unifies intrauterine growth retardation and preterm extrauterine growth retardation and has implications for the small-for-gestational-age indication in growth hormone therapy. Pediatrics 2006;117:e793-e795.

-59 Ong KK, Ahmed ML, Emmett PM, Preece MA, Dunger DB: Association between postnatal catch-up growth and obesity in childhood: prospective cohort study. BMJ 2000; 320:967-971.

60 Monset-Couchard M, de Bethmann O: Catch-up growth in 166 small-for- gestational age premature infants weighing less than 1,000 g at birth. Biol Neonate 2000;78:161167.

-61 Jordan IM, Robert A, Francart J, Sann L, Putet G: Growth in extremely low birth weight infants up to three years. Biol Neonate 2005; 88:57-65.

62 Trebar B, Traunecker R, Selbmann HK, Ranke MB: Growth during the first two years predicts pre-school height in children born with very low birth weight (VLBW): results of a study of 1,320 children in Germany. Pediatr Res 2007;62:209-214.

-63 Itabashi K, Mishina J, Tada H, Sakurai M, Nanri Y, Hirohata Y: Longitudinal follow-up of height up to five years of age in infants born preterm small for gestational age; comparison to full-term small for gestational age infants. Early Hum Dev 2007;83:327-333.

64 Rijken M, Wit JM, Le Cessie S, Veen S: The effect of perinatal risk factors on growth in very preterm infants at 2 years of age: the Leiden Follow-Up Project on Prematurity. Early Hum Dev 2007;83:527-534.

-65 Finken MJ, Dekker FW, de Zegher F, Wit JM: Long-term height gain of prematurely born children with neonatal growth restraint: parallelism with the growth pattern of short children born small for gestational age. Pediatrics 2006;118:640-643.
66 Saigal S, Stoskopf B, Streiner D, Paneth N, Pinelli J, Boyle M: Growth trajectories of extremely low birth weight infants from birth to young adulthood: a longitudinal, population-based study. Pediatr Res 2006;60:751758.

67 Brandt I, Sticker EJ, Gausche R, Lentze MJ: Catch-up growth of supine length/height of very low birth weight, small for gestational age preterm infants to adulthood. J Pediatr 2005; 147:662-668.

68 Doyle LW, Faber B, Callanan C, Ford GW, Davis NM: Extremely low birth weight and body size in early adulthood. Arch Dis Child 2004;89:347-350.

69 Ehrenkranz RA, Dusick AM, Vohr BR, Wright LL, Wrage LA, Poole WK: Growth in the neonatal intensive care unit influences neurodevelopmental and growth outcomes of extremely low birth weight infants. Pediatrics 2006;117:1253-1261.

70 Hack M, Breslau N, Weissman B, Aram D, Klein N, Borawski E: Effect of very low birth weight and subnormal head size on cognitive abilities at school age. N Engl J Med 1991;325: 231-237.

-71 Casey PH, Whiteside-Mansell L, Barrett K, Bradley RH, Gargus R: Impact of prenatal and/or postnatal growth problems in low birth weight preterm infants on school-age outcomes: an 8-year longitudinal evaluation. Pediatrics 2006;118:1078-1086.

72 Lucas A, Morley R, Cole TJ, Gore SM, Lucas PJ, Crowle P, Pearse R, Boon AJ, Powell R: Early diet in preterm babies and developmental status at 18 months. Lancet 1990;335: 1477-1481.

73 Lucas A, Morley R, Cole TJ: Randomised trial of early diet in preterm babies and later intelligence quotient. BMJ 1998;317:1481-1487.

74 Nosarti C, Al Asady MH, Frangou S, Stewart AL, Rifkin L, Murray RM: Adolescents who were born very preterm have decreased brain volumes. Brain 2002;125:1616-1623.

75 Luo ZC, Albertsson-Wikland K, Karlberg J: Length and body mass index at birth and target height influences on patterns of postnatal growth in children born small for gestational age. Pediatrics 1998;102:E72.

76 Amador-Licona N, Martinez-Cordero C, Guizar-Mendoza JM, Malacara JM, Hernandez J, Alcala JF: Catch-up growth in infants born small for gestational age: a longitudinal study. J Pediatr Endocrinol Metab 2007;20: 379-386.

77 Iniguez G, Ong K, Bazaes R, Avila A, Salazar T, Dunger D, Mericq V: Longitudinal changes in insulin-like growth factor-I, insulin sensitivity, and secretion from birth to age three years in small-for-gestational-age children. J Clin Endocrinol Metab 2006;91: 4645-4649.

78 Fewtrell MS, Cole TJ, Bishop NJ, Lucas A: Neonatal factors predicting childhood height in preterm infants: evidence for a persisting effect of early metabolic bone disease? J Pediatr 2000;137:668-673.
79 Farooqi A, Hagglof B, Sedin G, Gothefors L, Serenius F: Growth in 10- to 12-year-old children born at 23 to 25 weeks' gestation in the 1990s: a Swedish national prospective follow-up study. Pediatrics 2006;118:e1452e1465.

80 Schreiner F, Stutte S, Bartmann P, Gohlke B, Woelfle J: Association of the growth hormone receptor d3-variant and catch-up growth of preterm infants with birth weight less than 1,500 grams. J Clin Endocrinol Metab 2007;92:4489-4493.

81 Finken MJ, Meulenbelt I, Dekker FW, Frolich M, Romijn JA, Slagboom PE, Wit JM: The $23 \mathrm{~K}$ variant of the $\mathrm{R} 23 \mathrm{~K}$ polymorphism in the glucocorticoid receptor gene protects against postnatal growth failure and insulin resistance after preterm birth. J Clin Endocrinol Metab 2007;92:4777-4782.

82 Wood NS, Costeloe K, Gibson AT, Hennessy EM, Marlow N, Wilkinson AR: The EPICure study: growth and associated problems in children born at 25 weeks of gestational age or less. Arch Dis Child Fetal Neonatal Ed 2003;88:F492-F500.

83 Wang D, Vandermeulen J, Atkinson SA: Early life factors predict abnormal growth and bone accretion at prepuberty in former premature infants with/without neonatal dexamethasone exposure. Pediatr Res 2007;61: 111-116.

84 Romagnoli C, Zecca E, Luciano R, Torrioli G, Tortorolo G: A three year follow up of preterm infants after moderately early treatment with dexamethasone. Arch Dis Child Fetal Neonatal Ed 2002;87:F55-F58.

85 Doyle LW, Davis PG, Morley CJ, McPhee A, Carlin JB: Outcome at 2 years of age of infants from the DART study: a multicenter, international, randomized, controlled trial of low-dose dexamethasone. Pediatrics 2007; 119:716-721.

86 Watterberg KL, Gerdes JS, Cole CH, Aucott SW, Thilo EH, Mammel MC, Couser RJ, Garland JS, Rozycki HJ, Leach CL, Backstrom C, Shaffer ML: Prophylaxis of early adrenal insufficiency to prevent bronchopulmonary dysplasia: a multicenter trial. Pediatrics 2004;114:1649-1657.

87 Hintz SR, Kendrick DE, Stoll BJ, Vohr BR, Fanaroff AA, Donovan EF, Poole WK, Blakely ML, Wright L, Higgins R: Neurodevelopmental and growth outcomes of extremely low birth weight infants after necrotizing enterocolitis. Pediatrics 2005;115:696-703.

88 Gutbrod T, Wolke D, Soehne B, Ohrt B, Riegel K: Effects of gestation and birth weight on the growth and development of very low birthweight small for gestational age infants: a matched group comparison. Arch Dis Child Fetal Neonatal Ed 2000;82:F208F214.

89 Bracewell MA, Hennessy EM, Wolke D, Marlow N: The EPICure study: Growth and blood pressure at 6 years of age following extremely preterm birth. Arch Dis Child Fetal Neonatal Ed 2007;93:F108-114. 
\$0 Cutfield WS, Regan FA, Jackson WE, Jefferies CA, Robinson EM, Harris M, Hofman PL: The endocrine consequences for very low birth weight premature infants. Growth Horm IGF Res 2004; 14(suppl A): S130-S135.

-91 Niklasson A, Engstrom E, Hard AL, Wikland KA, Hellstrom A: Growth in very preterm children: a longitudinal study. Pediatr Res 2003;54:899-905.

$\checkmark 92$ Fewtrell MS, Lucas A, Cole TJ, Wells JC: Prematurity and reduced body fatness at 8-12 y of age. Am J Clin Nutr 2004;80:436440.

93 Ford GW, Doyle LW, Davis NM, Callanan C: Very low birth weight and growth into adolescence. Arch Pediatr Adolesc Med 2000; 154:778-784.

$\checkmark 94$ Hirata T, Bosque E: When they grow up: the growth of extremely low birth weight $(<$ or $=1,000 \mathrm{gm}$ ) infants at adolescence. J Pediatr 1998; 132:1033-1035.

$\checkmark 95$ Ericson A, Kallen B: Very low birthweight boys at the age of 19. Arch Dis Child Fetal Neonatal Ed 1998;78:F171-F174.

-96 Euser AM, Finken MJ, Keijzer-Veen MG, Hille ET, Wit JM, Dekker FW: Associations between prenatal and infancy weight gain and BMI, fat mass, and fat distribution in young adulthood: a prospective cohort study in males and females born very preterm. Am J Clin Nutr 2005;81:480-487.

97 Qvigstad E, Verloove-Vanhorick SP, EnsDokkum MH, Schreuder AM, Veen S, Brand R, Oostdijk W, Ruys JH: Prediction of height achievement at five years of age in children born very preterm or with very low birth weight: continuation of catch-up growth after two years of age. Acta Paediatr 1993;82:444-448

$\checkmark 98$ Barker DJ, Winter PD, Osmond C, Margetts B, Simmonds SJ: Weight in infancy and death from ischaemic heart disease. Lancet 1989;ii:577-580.

$\checkmark 99$ Schluchter MD: Publication bias and heterogeneity in the relationship between systolic blood pressure, birth weight, and catch-up growth: a meta analysis. J Hypertens 2003;1921:273-279.
100 Newsome CA, Shiell AW, Fall CH, Phillips DI, Shier R, Law CM: Is birth weight related to later glucose and insulin metabolism? A systematic review. Diabet Med 2003 20; 339-348.

101 Harder T, Rodekamp E, Schellong K, Dudenhausen JW, Plagemann A: Birth weight and subsequent risk of type 2 diabetes: a meta-analysis. Am J Epidemiol 2007; 165:849-857.

102 Eriksson JG, Forsen T, Tuomilehto J, Winter PD, Osmond C, Barker DJ: Catch-up growth in childhood and death from coronary heart disease: longitudinal study. BMJ 1999;318:427-431.

103 Forsen T, Eriksson JG, Tuomilehto J, Osmond C, Barker DJ: Growth in utero and during childhood among women who develop coronary heart disease: longitudinal study. BMJ 1999;319:1403-1407.

104 Lucas A, Fewtrell MS, Cole TJ: Fetal origins of adult disease-the hypothesis revisited. BMJ 1999;319:245-249.

105 Hales CN, Barker DJP: Type-2 (on-insulindependent) diabetes-mellitus - the thrifty phenotype hypothesis. Diabetologia 1992 . 35:595-601.

106 Hattersley AT, Tooke JE: The fetal insulin hypothesis: an alternative explanation of the association of low birthweight with diabetes and vascular disease. Lancet 1999; 353:1789-1792.

107 Hofman PL, Regan F, Cutfield WS: Prematurity: another example of perinatal metabolic programming? Horm Res 2006;66: 33-39.

108 Irving RJ, Belton NR, Elton RA, Walker BR: Adult cardiovascular risk factors in premature babies. Lancet 2000;355:2135-2136.

109 Ravelli AC, van der Meulen JH, Michels RP, Osmond C, Barker DJ, Hales CN, Bleker OP: Glucose tolerance in adults after prenatal exposure to famine. Lancet 1998;351: 173-177.

110 Mitanchez-Mokhtari D, Lahlou N, Kieffer F, Magny JF, Roger M, Voyer M: Both relative insulin resistance and defective islet beta-cell processing of proinsulin are responsible for transient hyperglycemia in extremely preterm infants. Pediatrics 2004; 113:537-541.
111 Regan FM, Cutfield WS, Jefferies C, Robinson E, Hofman PL: The impact of early nutrition in premature infants on later childhood insulin sensitivity and growth. Pediatrics 2006;118:1943-1949.

112 Hofman PL, Regan F, Jackson WE, Jefferies C, Knight DB, Robinson EM, Cutfield WS: Premature birth and later insulin resistance. N Engl J Med 2004;351:2179-2186.

113 Finken MJ, Keijzer-Veen MG, Dekker FW, Frolich M, Hille ET, Romijn JA, Wit JM: Preterm birth and later insulin resistance: effects of birth weight and postnatal growth in a population based longitudinal study from birth into adult life. Diabetologia 2006;49:478-485.

114 Finken MJ, Inderson A, van Montfoort N, Keijzer-Veen MG, van Weert AW, Carfil N, Frolich M, Hille ET, Romijn JA, Dekker FW, Wit JM: Lipid profile and carotid intima-media thickness in a prospective cohort of very preterm subjects at age 19 years: effects of early growth and current body composition. Pediatr Res 2006;59:604-609.

115 Keijzer-Veen MG, Finken MJ, Nauta J, Dekker FW, Hille ET, Frolich M, Wit JM, van der Heijden AJ: Is blood pressure increased 19 years after intrauterine growth restriction and preterm birth? A prospective follow-up study in The Netherlands. Pediatrics 2005;116:725-731.

116 Doyle LW, Faber B, Callanan C, Morley R: Blood pressure in late adolescence and very low birth weight. Pediatrics 2003;111:252257.

117 Hack M, Schluchter M, Cartar L, Rahman M: Blood pressure among very low birth weight $(<1.5 \mathrm{~kg})$ young adults. Pediatr Res 2005;58:677-684.

118 Kist-van Holthe JE, van Zwieten PH, SchellFeith EA, Zonderland HM, Holscher HC, Wolterbeek R, Veen S, Frolich M, van der Heijden BJ: Is nephrocalcinosis in preterm neonates harmful for long-term blood pressure and renal function? Pediatrics 2007; 119:468-475. 